\title{
Nematodes and rotifers on two Alpine debris-covered glaciers
}

\author{
R. S. AZZONI ${ }^{1}$, A. FRANZETTI ${ }^{2}$, D. FONTANETO ${ }^{3}$, A. ZULLINI ${ }^{4}$, \& R. AMBROSINI ${ }^{2 \star}$ \\ 1 “A. Desio" Department of Earth Sciences, University of Milano, Milano, Italy, ${ }^{2}$ Department of Earth and Environmental \\ Sciences (DISAT), University of Milano-Bicocca, Milano, Italy, ${ }^{3}$ National Research Council, Institute of Ecosystem Study \\ (ISE-CNR), Verbania Pallanza, Italy, and ${ }^{4}$ Department of Biotechnology and Biosciences, University of Milano-Bicocca, \\ Milano, Italy
}

(Received 9 March 2015; accepted 21 fuly 2015)

\begin{abstract}
Debris-covered glaciers (DCGs) are glaciers whose ablation area is mostly covered by a continuous layer of debris, and are considered to be among the continental glacierized environments richest in life. DCG colonization by microorganisms, plants and animals, has been investigated in a few studies, while the meiofauna (metazoans smaller than $2 \mathrm{~mm}$ ) of these environments has been neglected so far. In this study, we analyzed nematode and rotifer fauna on the two largest debriscovered glaciers of the Italian Alps: the Miage Glacier and the Belvedere Glacier. In total, we collected 38 debris samples on the glaciers in July and September 2009. All the rotifers we found belonged to the bdelloid Adineta vaga (Davis, 1873). Nematodes belonged to 19 species. Miage Glacier hosted a richer and more diverse nematode fauna than the Belvedere. The dominant genus was Plectus Bastian, 1865, a common genus in habitats at high latitude and altitude. Analysis of the feeding type of nematodes highlighted that bacterivores were dominant on Miage Glacier, while bacterivores and herbivores were more widespread on Belvedere Glacier. Predator nematodes were absent. Analysis of the food-web structure indicated that nematode assemblages on both glaciers were typical of environments with depleted food availability, probably resulting from instability of the glacier surface and the short exposure of sediments, preventing the evolution of true soil and enrichment in organic matter of the debris. The scarcity of bacterial primary producers suggests that deposition of allochthonous organic matter is the principal organic carbon source in this environment.
\end{abstract}

Keywords: Belvedere Glacier, food-depleted food-webs, meiofauna, Miage Glacier, structure index

\section{Introduction}

The cryosphere is the part of the world where water is frozen, either for long periods or seasonally (LaybournParry et al. 2012). It includes ice caps and ice sheets, glaciers, lake ice, snow cover and permafrost on the continents, and sea ice on the oceans (Laybourn-Parry et al. 2012). While at first glance these extreme environments may seem not to host habitats that can support life, they have been proven to sustain active ecological processes, and are now considered ecosystems (Hodson et al. 2008). Sea ice is particularly well studied in this respect (see, e.g., Gradinger 2001), but recently also glaciers and ice sheets have been proposed as biomes in their own right (Anesio \& Laybourn-Parry 2012). The surface of glaciers can be colonized by bacterial and algal communities (Takeuchi et al. 2001; Hodson et al. 2008; Schütte et al. 2010), as well as by communities of multicellular organisms, such as mosses, which, in turn, could be inhabited by species of Tardigrada, Nematoda, Enchytraeidae and Arachnida (Coulson \& Midgley 2012). However, many other cryophilic invertebrates, mostly connected with aquatic/semi-aquatic environments, such as Chironomidae (Kohshima 1984), Plecoptera (Kohshima 1985), Collembola (Fjellberg 2010) and Enchytraeidae (Shain et al. 2001), can live directly on the surface of the ice (Zawierucha et al. 2015). Moreover, supraglacial cryoconite holes can be considered biodiversity hotspots for invertebrates such as Copepoda, Annelida, Tardigrada, Nematoda and Rotifera inhabiting glacial ecosystems (Zawierucha et al. 2015).

The debris cover of debris-covered glaciers (DCGs) is probably one of the continental glacierized

*Correspondence: Roberto Ambrosini, Department of Earth and Environmental Sciences (DISAT), University of Milano-Bicocca, Piazza della Scienza 1, 20126 Milano, Italy. Tel: +39 02 64483464. Fax: +39 02 64483565. Email: roberto.ambrosini@unimib.it

(C) 2015 Unione Zoologica Italiana 
environments richest in life (Nakawo et al. 2000). DCGs are mountain glaciers whose ablation area is mostly covered by a continuous layer of debris mainly composed of clasts, ranging in size from millimeters to meters, which fall on the glacier surface from surrounding mountains (Hambrey et al. 2008). The debris is then transported down valley by glacier movements for times that, on some glaciers, can be as long as a century (Pelfini et al. 2007). Most of the ablation area of DCGs is therefore covered by a continuous debris layer, whose thickness generally increases toward the glacier terminus (Hambrey et al. 2008). The thick debris cover of DCGs reduces ice ablation (Nakawo \& Rana 1999), but the debris surface can be heated by solar radiation to temperatures that can exceed $+30^{\circ} \mathrm{C}$ (Brock et al. 2010). During the long transport on the glacier surface, the debris is weathered and altered, and can be colonized by microorganisms (Franzetti et al. 2013), plants (if the glacier elevation is lower than the treeline; Pelfini et al. 2007, 2012; Caccianiga et al. 2011) and animals (Gobbi et al. 2011). It is important to note that not only pioneer organisms can live on the surface of DCGs. For example, trees up to $2 \mathrm{~m}$ high grow on the surface of the Miage Glacier (Caccianiga et al. 2011), and herbaceous plants can colonize DCG surfaces above the tree line, suggesting that organisms typical of soil fauna can live in the debris of DCGs.

The fauna of soils is mainly composed by microscopic organisms such as nematodes, rotifers and tardigrades, while larger ones, such as springtails, mites and other arthropods, are less abundant (Coleman et al. 2004; Chesworth 2008). Nematodes, rotifers and tardigrades, forming the so-called "meiofauna" of the soil, have been found in debris and thin soils from extreme habitats connected to ice in different areas of the world, including the polar regions (Sohlenius et al. 1996). Nematodes are the dominant phylum in soil, where they are present at densities ranging from one to several million individuals per square meter. Specific studies of nematodes in glacial environments are lacking. Nkem et al. (2006) found on the Antarctic ice only three nematode species: Plectus antarcticus de Man, 1904, Eudorylaimus antarcticus (Steiner, 1916) and Scottnema lindsayae Timm, 1971. Rotifers are usually less abundant in soils than nematodes, but they were found to be relatively more abundant in areas surrounding glaciers, such as Antarctic soils (Convey \& McInnes 2005; Fontaneto et al. 2015).

Since nematodes and rotifers have been found in glacial environments, they may be present also in the debris cover of DCGs, but no study on their occurrence in these environments is known to us. In this study, we present a first report on the nematode and rotifer fauna found in the debris cover of two DCGs of the Italian Alps, the Miage Glacier (Valle d'Aosta, Italy) and the Belvedere Glacier (Piemonte, Italy), and analyze the structure of the nematode assemblages we found.

\section{Methods}

\section{Study sites and field methods}

Miage Glacier $\left(45^{\circ} 47^{\prime} \mathrm{N}, 6^{\circ} 52^{\prime} \mathrm{E}\right.$, Mont Blanc massif) is the widest DCG of the Italian Alps, with a total surface area of $10.47 \mathrm{~km}^{2}$ (2009 data, Smiraglia et al. 2015). Its ablation zone is covered by debris from above $2400 \mathrm{~m}$ above sea level (a.s.1.) to the terminus (1700 $\mathrm{m}$ a.s.1.). The debris covers $4 \mathrm{~km}^{2}$ and is mainly composed by gneisses, schists and granites (Brock et al. 2010), and ranges in thickness from a few centimeters to more than $1 \mathrm{~m}$ at the snout of the glacier (Mihalcea et al. 2008).

Belvedere Glacier $\left(45^{\circ} 57^{\prime} \mathrm{N}, 7^{\circ} 55^{\prime} \mathrm{E}\right.$, Monte Rosa massif) has a total surface area of $4.53 \mathrm{~km}^{2}$ (2010 data, Smiraglia et al. 2015) and is debris-covered from about $2300 \mathrm{~m}$ a.s.1. to the glacier snout at $1750 \mathrm{~m}$ a.s.1. Rock debris is mainly composed by gneisses, micaschists and granites with a thickness ranging from a few centimeters to more than $1 \mathrm{~m}$ at the terminus (Diolaiuti et al. 2003).

During each of the sampling campaigns, debris samples were collected both on July (the 28th on Miage and the 2nd on Belvedere) and September (the 10th on Miage and the 18th on Belvedere) 2009 at the same locations, with the only exception of one site on the Miage Glacier, where in September a crevasse prevented us from reaching the same sampling site as in July (Figure 1). Nine debris samples (approximately $500 \mathrm{~mL}$ ) were collected at the surface of the debris cover of Miage Glacier from 1749 to $2169 \mathrm{~m}$ a.s.1., and 10 at that of the Belvedere Glacier from 1803 to $2085 \mathrm{~m}$ a.s.1. At all sampling sites we removed the dry debris (< $1 \mathrm{~cm}$ ) at the very surface of the debris cover, and collected the first few centimeters of the underlying fresh and moist debris. Collecting samples deeper was impractical, due to the presence of large stones or iced debris close to the glacier surface. On both glaciers, sampling sites were chosen at approximately constant intervals (elevation and distance) from the glacier terminus (Figure 1). Overall, we collected 18 debris samples from Miage Glacier and 20 from Belvedere Glacier.

This sampling design was chosen because we originally aimed at assessing whether the structure of nematode and rotifer assemblages changed along the glacier, and to identify the ecological variables driving such variation. For this aim, we also collected 


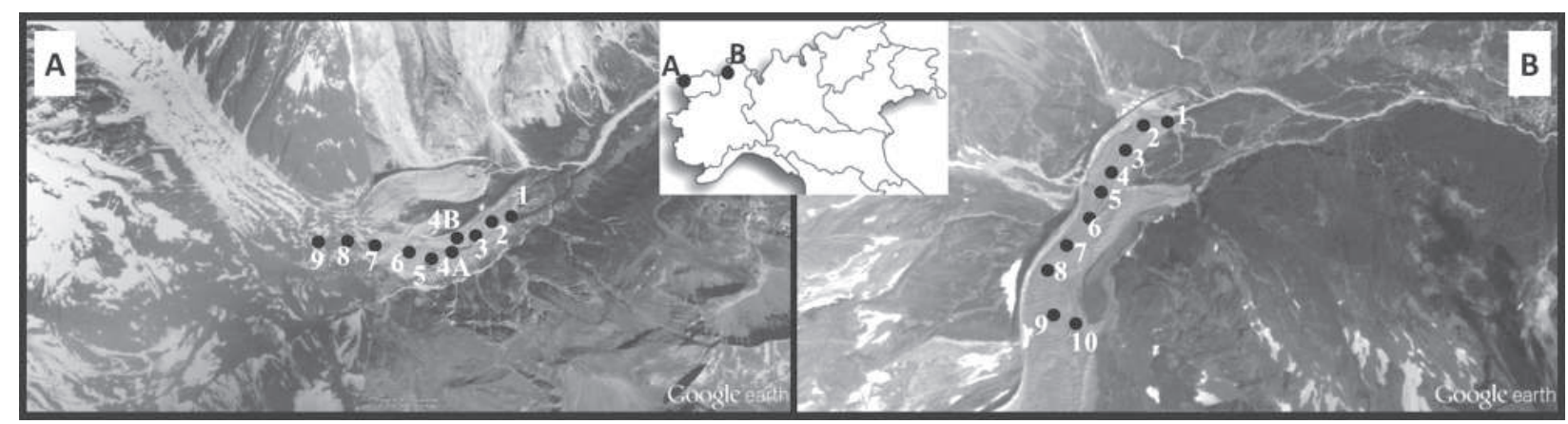

Figure 1. Sampling sites A, on the Miage Glacier and B, on Belvedere Glacier, from Google Earth ${ }^{\mathrm{TM}}$. Site 4 on Miage Glacier was sampled at different positions in July and September.

information on several features of the environment at each sampling site (namely elevation, debris thickness, annual surface velocity, organic carbon content and $\mathrm{pH}$ ) by methods that are fully described in Franzetti et al. (2013). However, the number of individual nematodes and rotifers collected in each sample (about six nematodes and one rotifer per sample on average; see Results) was too low to perform any statistical analysis at the site level. We also considered that, even if we had extracted nematodes and rotifers from the whole amount of debris collected in each sample, and not from a sub-sample (see below), the number of individuals extracted would have been too low to perform any analysis at the site level. We therefore considered our samples as replicated samples collected at the same glacier, and performed all of the analyses with only the aim of describing and comparing nematode and rotifer faunas living in the debris cover of the Miage and Belvedere glaciers. All information on environmental variables was therefore discarded.

\section{Nematode and rotifer extraction and identification}

Each debris sample was mixed, and a $200 \mathrm{~mL}$ subsample extracted. Nematodes were extracted from the sub-sample by a modified Baermann method (Baermann 1917). Briefly, the debris was folded in tissue paper and placed on a wire mesh that, in turn, was put in a dish filled with water. This method for nematode extraction takes advantage of the natural tendency of nematodes to move toward the water, crossing the debris. After two days of incubation at room temperature, we collected the nematodes in the dish and fixed them in dimethyl sulfoxide solution (Kilpatrick 2002). Transfer and mounting of nematodes on permanent slides followed standard methods (Seinhorst 1959). Taxonomy and nomenclature of nematodes followed Peneva and Bongers (2013).
Rotifers were extracted from the sub-samples using Devetter's (2010) method: briefly, $20 \mathrm{~mL}$ of soil sample were spread on a plastic sieve with a very thin layer of cellulose submerged in distilled water in a Petri dish. The Petri dish was situated on a cooled panel and lit from the top with fluorescent lamps. The temperature of the base panel was $+5^{\circ} \mathrm{C}$, whereas no heating from the top was used, as it is known to reduce extraction efficiency for rotifers (Devetter 2010). In addition, in order to check that no additional slow-moving rotifers or animals that do not detach from soil particles were present, $20 \mathrm{~mL}$ of soil sample was put in Petri dishes with water and directly observed using a microscope, to look for living animals. Taxonomic identification of rotifers followed Donner (1965), whereas the adopted nomenclature was that of the recent List of Available Names for rotifers (Segers et al. 2012).

Data analysis. We investigated nematode diversity at each glacier by calculating Simpson and Shannon (base e) diversity indices. We also aimed to estimate the total number of nematode species on each glacier, given the observed species. Several tools are described in the literature for these estimates, based on both parametric and non-parametric methods, but the application of different tools to the same data set usually provides different estimates (Hill et al. 2003). To mitigate the impact of this (unavoidable) problem, we used the CatchAll software (beta 4 version; Bunge et al. 2012, http://www.northeastern.edu/ catchall/). CatchAll fits four parametric models via maximum likelihood and five non-parametric richness estimates to the data. The best model is then chosen as the model that shows the best fit to the data, i.e., that has both low standard error (SE) of the estimated total number of species in the community and low values of the goodness-of-fit (GOF) statistic on the observed data (Hong et al. 2006; Bunge et al. 2012; also see the CatchAll manual for further details at 
www.northestern.edu/catchall/downloads/CatchAll. manual.2.0.pdf).

We also compared the relative abundance of each species (the number of individuals of each taxon divided by the total number of individuals collected on each glacier) between the two glaciers using a binomial mixed model, where the glacier was entered as a dichotomous fixed factor and species as a random factor. The glacier was also entered as a random slope within species. This model is analogous to a paired sample t-test, but accounts for the non-Gaussian distribution of relative abundances (Zuur et al. 2009).

We analyzed the nematode species we found following the Ferris et al. (2001) concepts and criteria. The nematode fauna provides information on the food webs of a soil, particularly on their complexity and connectance (the proportion of possible links between species that are realized; Dunne et al. 2002) and on how resources flow in them (Ferris et al. 2001). Briefly, nematodes can be divided into functional guilds according to their feeding habits (bacterivores, fungivores, herbivores, carnivores and omnivores), and their position along a colonizerpersistent ( $c-p)$ gradient (partially reflecting the $r-K$ strategist gradient of the species; Bongers 1990). Abundance of nematode functional guilds can be used to calculate two indices, a Structure Index (SI) indicating whether the food web is simple (low values) or complex (high values), and the Enrichment Index (EI) indicating whether a soil is depleted (low values) or enriched (high values) in organic matter (Ferris et al. 2001). Both indices range from 1 to 100 and depict different and independent pieces of information on soil features (Ferris et al. 2001). They can be used to draw a "functional guilds square", which is a Cartesian plot with the SI as the $\mathrm{x}$-axis and the EI as the y-axis. The square can be then divided into quadrants according to values of both indices being larger or smaller than 50. Since the SI and the EI indices are independent, nematode assemblages can be found anywhere in the square (Ferris et al. 2001). Given the small number of specimens found at each sampling site, analyses of nematode presence were run by pooling together all of the individuals collected on each glacier from both sampling campaigns. Analyses were made with the Nematode INdicator Joint Analysis (NINJA) software (Sieriebriennikov et al. 2014; http://spark.rstu dio.com/bsierieb/ninja/).

\section{Results}

Nematodes were found in 11 of the 18 samples (61\%) collected on Miage Glacier, and in 16 of the 20 samples $(80 \%)$ collected on Belvedere Glacier. The average number of individuals collected in each sample was $5.8 \pm 1.5$ SE (range 0-46, $\mathrm{n}=38$ samples).

We identified 19 nematode taxa (Table I). In 14 cases we were able to identify taxa to the species level, while in five cases only to the genus level. Only in the case of Tylencholaimus sp. de Man, 1876 was more than one individual found. However, in this case, the two specimens were indistinguishable; therefore, we consider them to belong to the same species, albeit we could not precisely assess which one.

On the Miage Glacier the most abundant species was Plectus rhizophilus de Man, 1880 (20 individuals), while on the Belvedere Glacier it was Tylenchus davainei Bastian, 1865 (57 individuals). Considering both glaciers, all Nematodes assemblages were dominated by Plectus pusteri Fuchs, 1930 and Tylenchus davainei. Nematode diversity was larger on the Miage (14 taxa) than on the Belvedere Glacier (nine taxa), but the total number of organisms sampled was higher on Belvedere (137) than on Miage Glacier (83). Both Simpson and Shannon diversity indices were larger on the Miage than on the Belvedere Glacier (Table I). Total estimated number of species was also larger for the Miage (16.8 $\pm 2.0 \mathrm{SE}$, confidence limits: $14.8-$ 24.0) than for the Belvedere Glacier (11.7 \pm 2.7 SE, confidence limits: 9.5-23.0). However, the confidence limits of these estimates overlap.

The relative abundance of nematodes was larger on the Miage than on the Belvedere Glacier $(z=2.11$, $P=0.03$ ), thus suggesting that the structure of nematode assemblages differed between the two glaciers. We then pooled together all specimens collected on each glacier to investigate nematode feeding types. This analysis confirmed that nematode assemblages differed between the two glaciers (Figure 2). In the supraglacial debris of Miage Glacier bacterivores were the dominant feeding type, while omnivores, fungivores and herbivores were limited. On the contrary, in the debris of Belvedere Glacier, the two dominant feeding types were bacterivores and herbivores. Predators were absent on both glaciers.

Rotifers were found in six samples collected on the Miage and in seven samples collected on the Belvedere Glacier. Overall, 38 individuals were found, all belonging to the bdelloid species Adineta vaga (Davis, 1873). The average number of individuals collected at each sample was $1.0 \pm 0.3 \mathrm{SE}$ (range $0-8, \mathrm{n}=38$ samples). No analysis of the rotifer communities was therefore possible.

\section{Discussion}

This work reports a first assessment of nematodes and rotifers living in the debris cover of two Alpine 
Table I. Nematodes identified in the debris collected on Miage and Belvedere glaciers. Species whose identification was uncertain are indicated with "??". The number of individuals per taxon observed on each glacier is reported. The colonizer-persistent (c-p) gradient consists of five classes: the lower values identify opportunist organisms; the higher values indicate persistent nematodes. In the feeding type column, " $\mathrm{H}$ " indicates herbivores, " $\mathrm{F}$ " fungivores, "B" bacterivores and "O" omnivores. Nematode weight was calculated according to Andrássy (1956).

\begin{tabular}{|c|c|c|c|c|c|}
\hline \multirow[t]{2}{*}{ Species/genus } & \multicolumn{2}{|c|}{ Total number of individuals } & \multirow[t]{2}{*}{ c-p class } & \multirow{2}{*}{$\begin{array}{l}\text { Feeding } \\
\text { type }\end{array}$} & \multirow{2}{*}{$\begin{array}{c}\text { Mass } \\
(\mu \mathrm{g})\end{array}$} \\
\hline & Miage & Belvedere & & & \\
\hline Coslenchus sp. Siddiqi, 1978 & 1 & 0 & 0 & $\mathrm{H}$ & 0.11 \\
\hline Malenchus bryophilus (Steiner, 1914) & 5 & 0 & 0 & $\mathrm{H}$ & 0.06 \\
\hline Tylenchus davainei Bastian, 1865 & 2 & 57 & 0 & $\mathrm{H}$ & 0.64 \\
\hline Tylenchus elegans de Man, 1876 & 0 & 9 & 0 & $\mathrm{H}$ & 0.45 \\
\hline Xenocriconemella macrodora (Taylor, 1936) & 1 & 0 & 0 & $\mathrm{H}$ & 0.15 \\
\hline Aphelenchoides pusillus (Thorne, 1929) & 2 & 5 & 2 & $\mathrm{~F}$ & 0.16 \\
\hline Tylencholaimus sp. & 2 & 0 & 4 & $\mathrm{~F}$ & 0.51 \\
\hline Acrobeloides tricornis? (Thorne, 1925) & 0 & 4 & 2 & $\mathrm{~B}$ & 0.17 \\
\hline Cephalobus sp. Bastian, 1863 & 0 & 1 & 2 & B & 0.27 \\
\hline $\begin{array}{l}\text { Eumonhystera longicaudatula Gerlach } \\
\quad \text { \& Riemann, } 1973\end{array}$ & 0 & 6 & 2 & $\mathrm{~B}$ & 0.12 \\
\hline Chiloplectus andrassyi (Timm, 1971) & 2 & 0 & 2 & B & 0.97 \\
\hline Plectus geophilus de Man, 1880 & 10 & 0 & 2 & B & 0.07 \\
\hline Plectus magadani Kuzmin, 1979 & 0 & 4 & 2 & B & 0.45 \\
\hline Plectus parietinus Bastian, 1865 & 1 & 0 & 2 & B & 2.41 \\
\hline Plectus parvus Bastian, 1865 & 7 & 1 & 2 & B & 0.14 \\
\hline Plectus pusteri Fuchs, 1930 & 18 & 50 & 2 & B & 1.17 \\
\hline Plectus rhizophilus de Man, 1880 & 20 & 0 & 2 & B & 0.63 \\
\hline Prismatolaimus intermedius Bütschli, 1873 & 2 & 0 & 3 & $\mathrm{~B}$ & 0.11 \\
\hline $\begin{array}{l}\text { Eudorylaimus brevis (Andrássy, 1958)/ } \\
\text { discolaimoideus (Andrássy, 1958) }\end{array}$ & 10 & 0 & 4 & $\mathrm{O}$ & 3.40 \\
\hline Total number of individuals & 83 & 137 & & & \\
\hline Number of species & 14 & 9 & & & \\
\hline Shannon diversity index (base $e$ ) & 2.17 & 1.45 & & & \\
\hline Simpson diversity index & 0.85 & 0.68 & & & \\
\hline
\end{tabular}

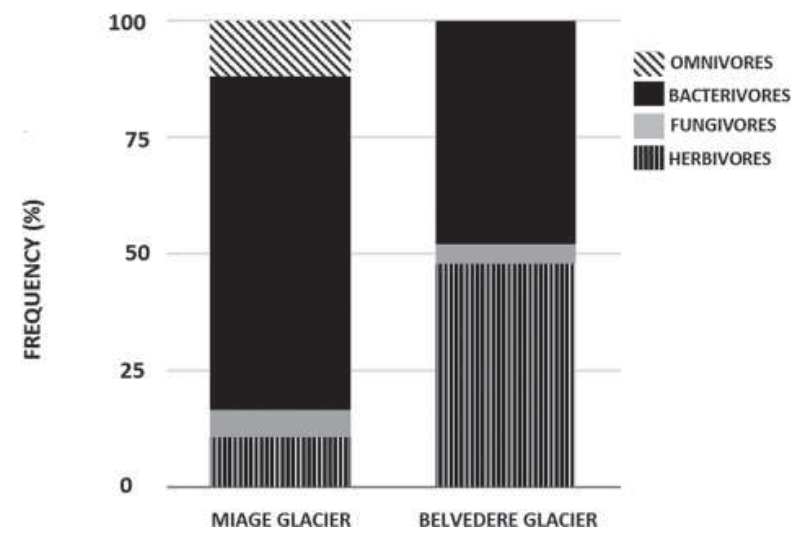

Figure 2. Feeding type composition of nematode assemblages found on the Miage and Belvedere glaciers.

DCGs. The food webs of nematode assemblages, dominated by Plectus pusteri and Plectus rhizophilus on the Miage and by Plectus pusteri and Tylenchus davainei on the Belvedere Glacier, were classified by the NINJA software as "basal" (Figure 3), i.e., "food webs that have been diminished due to stress,

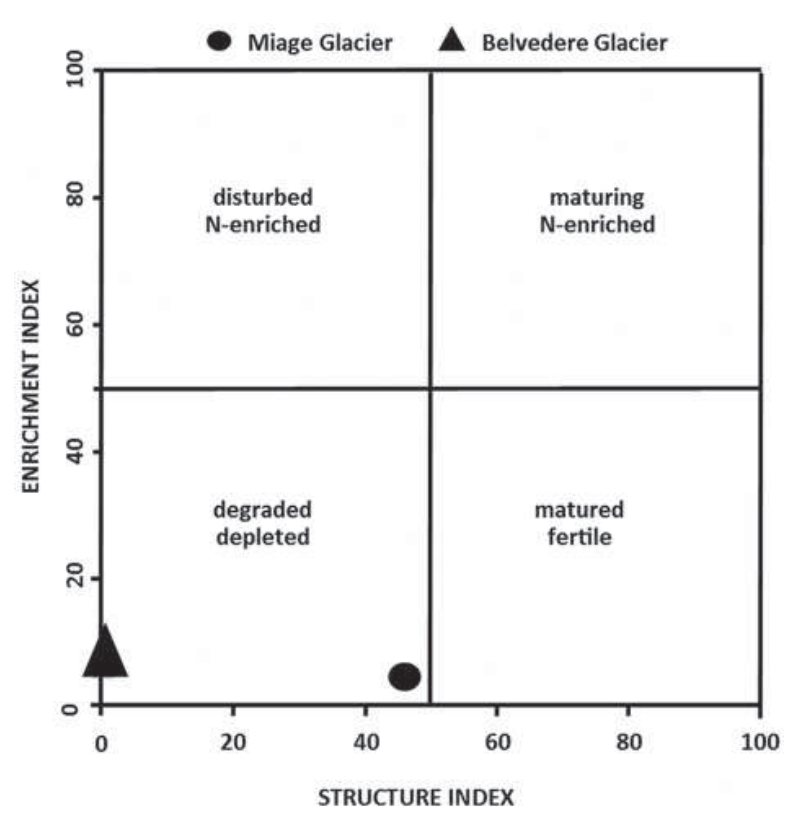

Figure 3. Analysis of the nematode assemblages performed with the Nematode INdicator Joint Analysis (NINJA) software (Sieriebriennikov et al. 2014). 
including limitation of resources, adverse environmental conditions, or recent contamination" (Ferris et al. 2001; see also Sieriebriennikov et al. 2014). This result suggests that, while DCGs can be considered among the continental glacier environments richest in life, the ecological conditions in their debris may pose adverse and stressful conditions to soil organisms. In fact, these habitats are characterized by substrate instability due to the glacier motion (up to $76 \mathrm{~m}$ per year, on the Miage Glacier; Pelfini et al. 2007) and rather short exposure of sediments to weathering (less than one century; Pelfini et al. 2007) that prevent the evolution of a supraglacial soil and enrichment in organic matter. Moreover, the debris coverage is characterized by large daily and annual temperature variations (Mihalcea et al. (2008) reported temperature excursions of up to $+50^{\circ} \mathrm{C}$ on the Miage Glacier), which probably negatively affect soil meiofauna because only very eurythermic species can survive in this environment. In addition, low trophic resource availability, as indicated by the very basal nematode food webs we found, may pose further limits to meiofauna abundance and richness.

Despite the few nematode taxa identified, some ecological patterns are evident. There is a clear dominance of Plectus, both in individuals (51\%) and in species (37\%), for all assemblages. Plectus is usually dominant at high latitudes and altitudes all over the world (Artois et al. 2011), and dominance by this genus confirms that the adverse environmental conditions at the surface of DCGs are the most probable forcing factor affecting ecological assemblages living in these environments. Overall, the Miage seems to host more diverse nematodes than the Belvedere Glacier does. This may be due to the thicker and more stable debris layer that covers this glacier (Diolaiuti et al. 2003; Mihalcea et al. 2008). The majority of the nematodes we found were bacterivores, whereas predators were absent. This is consistent with the results of other studies suggesting that the principal organic carbon source of the trophic web might be the deposition of allochthonous organic matter (Stibal et al. 2008; Franzetti et al. 2013). Although it has been reported that photosynthetic bacteria and unicellular algae may constitute the main food source of soil nematodes in High-Arctic cryo-ecosystems, the composition of the microbial community on DCGs did not show significant abundance of phototrophs (Franzetti et al. 2013). Moreover, Gobbi et al. (2011) investigated the arthropod communities on the Miage Glacier, and found that they are sustained by inputs of organic matters (i.e. plant debris, insects, animal excrement) from the surrounding areas. External inputs support the supraglacial vegetation as well (Caccianiga et al. 2011), providing resources necessary to sustain the occurrence of plants (e.g., leaves or plant debris). All of this evidence suggests that trophic webs on DCGs are sustained from allochthonous inputs of organic matter from surrounding environments.

Whereas our initial aim was to investigate variation in rotifer and nematode assemblages along the glacier surface, the paucity of the specimens we found prevented any analysis at site level. Future studies aiming at investigating rotifer and nematode communities in these environments should therefore collect and extract nematodes from a much larger amount of debris (at least $2000 \mathrm{~mL}$ ), in order to obtain about 200 individuals on average from each sample, corresponding to a minimum amount for performing nematode analyses (Lison 1960).

Surprisingly, rotifer diversity was very low, with only one species, $A$. vaga, and few individuals. $A$. vaga is a cosmopolitan species living in any habitat and under very different conditions; moreover, it is known to be a complex of several taxa, each of them potentially with different ecological needs (Fontaneto et al. 2011). Thus, no ecological inference can be performed based only on the morphological identification of this taxon. Rotifers, and especially bdelloid rotifers, are known to be common and sometimes extremely abundant in Arctic (Kaya et al. 2010) and Antarctic environments (Fontaneto et al. 2015) as well as at elevations higher than $3000 \mathrm{~m}$ a.s.l. in the Alps (Fontaneto \& Ricci 2006). Yet, even from well-studied areas in Antarctica, most records of rotifers do not come from bare periglacial soils, but are almost invariably from more structured soils, usually with moss carpets (Fontaneto et al. 2015). Records of rotifers from glaciated habitats such as cryoconite holes also include one or few species (Zawierucha et al. 2015), suggesting that the surface of DCGs could actually be a truly rotifer-poor habitat. The limiting factor for the low abundance and diversity of rotifers in DCG surfaces is not the freezing temperature, but we can speculate that the low rotifer diversity could be related to the texture or to the dynamics of organic matter of the debris. However, we stress that very little is known about soil rotifers and the drivers of their diversity, so our hypotheses are merely tentative.

In summary, our results indicate that ecological assemblages on DCGs depend on inputs of organic matter from surrounding environments. Pioneer communities in extreme environments may not necessarily be dominated by primary producers, but can be composed of consumers degrading organic matter mainly coming from other ecosystems.

\section{Acknowledgements}

We gratefully thank Alessia Sacchetti for help during field and lab work, J. Bunge and L. Woodard for kindly 
providing the CatchAll beta. 4 software, and three anonymous referees whose comments improved the quality of the paper. The work was funded by the 2009 FAR grant n. 12/1-10 to RA.

\section{References}

Andrássy I. 1956. Die Rauminhalts- und Gewichtsbestimmung der Fadenwürmer (Nematoden). Acta Zoologica 2:1-15.

Anesio AM, Laybourn-Parry J. 2012. Glaciers and ice sheets as a biome. Trends in Ecology and Evolution 27:219-225. doi:10.1016/j.tree.2011.09.012.

Artois T, Fontaneto D, Hummon WD, McInnes SJ, Todaro MA, Sørensen MV, Zullini A. 2011. Ubiquity of microscopic animals? Evidence from the morphological approach in species identification. In: Fontaneto D, editor. Biogeography of microscopic organisms, is everything small everywhere? Cambridge: Cambridge University Press. pp. 244-283.

Baermann G. 1917. Eine einfache Methode zur Auffindung von Ankylostomum- (Nematoden) -Larven in Erdproben. Weltevreden Batavia: Geneesk. Lab. Feestbundel. pp. 41-47.

Bongers T. 1990. The maturity index: An ecological measure of environmental disturbance based on nematode species composition. Oecologia 83:14-19. doi:10.1007/BF00324627.

Brock BW, Mihalcea C, Kirkbride MP, Diolaiuti G, Cutler MEJ, Smiraglia C. 2010. Meteorology and surface energy fluxes in the 2005-2007 ablation seasons at the Miage debris-covered glacier, Mont Blanc Massif, Italian Alps. Journal of Geophysical Resources 115:D09106.

Bunge J, Woodard L, Böning D, Foster JA, Connolly S, Allen HK. 2012. Estimating species diversity with CatchAll. Bioinformatics 28:1045-1047. doi:10.1093/bioinformatics/bts075.

Caccianiga M, Andreis C, Diolaiuti G, D'Agata C, Mihalcea C, Smiraglia C. 2011. Alpine debris-covered glaciers as a habitat for plant life. The Holocene 21:1011-1020. doi:10.1177/ 0959683611400219.

Chesworth W. 2008. Encyclopedia of Soil Science. Dordrecht: Springer.

Coleman DC, Crossley DA, Hendrix PF. 2004. Fundamentals of Soil Ecology. San Diego: Elsevier Academic Press.

Convey P, McInnes SJ. 2005. Exceptional tardigrade-dominated ecosystems in Ellsworth Land. Antarctica. Ecology 86:519527. doi:10.1890/04-0684.

Coulson SJ, Midgley NG. 2012. The role of glacier mice in the invertebrate colonisation of glacial surfaces: The moss balls of the Falljo kull. Iceland. Polar Biology 35:1651-1658. doi:10.1007/s00300-012-1205-4.

Devetter M. 2010. A method for efficient extraction of rotifers (Rotifera) from soils. Pedobiologia 53:115-118. doi:10.1016/j. pedobi.2009.07.001.

Diolaiuti G, D’Agata C, Smiraglia C. 2003. Belvedere Glacier, Monte Rosa, Italian Alps: Tongue thickness and volume variations in the second half of the 20th century. Arctic, Antarctic and Alpine Research 35:255-263. doi:10.1657/1523-0430 (2003)035[0255:BGMRIA]2.0.CO;2.

Donner J. 1965. Ordnung Bdelloidea (Rotatoria, Rädertiere). Bestimmungsbücher zur Bodenfauna Europas. Vol. 6. Berlin: Akademie Verlag.

Dunne JA, Williams RJ, Martinez ND. 2002. Food-web structure and network theory: The role of connectance and size. Proceedings of the National Academy of Sciences 99:1291712922. doi:10.1073/pnas. 192407699.
Ferris H, Bongers T, De Goede RGM. 2001. A framework for soil food web diagnostics: Extension of the nematode faunal analysis concept. Applied Soil Ecology 18:13-29. doi:10.1016/ S0929-1393(01)00152-4.

Fjellberg A. 2010. Cryophilic isotomidae (Collembola) of the Northwestern Rocky Mountains, U.S.A. Zootaxa 2513:27-49.

Fontaneto D, Iakovenko N, De Smet WH. 2015. Diversity gradients of rotifer species richness in Antarctica. Hydrobiologia in press. 10.1007/s10750-015-2258-5

Fontaneto D, Iakovenko N, Eyres I, Kaya M, Wyman M, Barraclough TG. 2011. Cryptic diversity in the genus Adineta Hudson \& Gosse, 1886 (Rotifera: Bdelloidea: Adinetidae): A DNA taxonomy approach. Hydrobiologia 662:27-33. doi:10.1007/s10750-010-0481-7.

Fontaneto D, Ricci C. 2006. Spatial gradients in species diversity of microscopic animals: The case of bdelloid rotifers at high altitude. Journal of Biogeography 33:1305-1313. doi:10.1111/ jbi.2006.33.issue-7.

Franzetti A, Tatangelo V, Gandolfi I, Bertolini V, Bestetti G, Diolaiuti GA, D'Agata C, Mihalcea C, Smiraglia C, Ambrosini R. 2013. Bacterial community structure on two alpine debris-covered glaciers and biogeography of Polaromonas phylotypes. The ISME Journal 7:1483-1492. doi:10.1038/ismej.2013.48.

Gobbi M, Isaia M, De Bernardi F. 2011. Arthropod colonisation of a debris-covered glacier. The Holocene 21:343-349. doi:10.1177/0959683610374885.

Gradinger RR. 2001. Adaptation of Arctic and Antarctic ice metazoa to their habitat. Zoology 104:339-345. doi:10.1078/09442006-00039.

Hambrey MJ, Quincey DJ, Glasser NF, Reynolds JM, Richardson SJ, Clemmens S. 2008. Sedimentological, geomorphological and dynamic context of debris-mantled glaciers, Mount Everest (Sagarmatha) region, Nepal. Quaternary Science Reviews 27:2361-2389. doi:10.1016/j.quascirev.2008.08.010.

Hill TCJ, Walsh KA, Harris JA, Moffett BF. 2003. Using ecological diversity measures with bacterial communities. FEMS Microbiology Ecology 43:1-11. doi:10.1111/j.15746941.2003.tb01040.x.

Hodson A, Anesio AM, Tranter M, Fountain A, Osborn M, Priscu J, Laybourn-Parry J, Sattler B. 2008. Glacial ecosystem. Ecological Monographs 78:41-67. doi:10.1890/07-0187.1.

Hong SH, Bunge J, Jeon SO, Epstein SS. 2006. Predicting microbial species richness. Proceedings of the National Academy of Sciences USA 103:117-122. doi:10.1073/pnas.0507245102.

Kaya M, De Smet WH, Fontaneto D. 2010. Survey of mossdwelling bdelloid rotifers from middle Arctic Spitsbergen (Svalbard). Polar Biology 33:833-842. doi:10.1007/s00300009-0761-8.

Kilpatrick CW. 2002. Non-cryogenic preservation of mammalian tissues for DNA extraction: An assessment of storage methods. Biochemical Genetics 40:53-62. doi:10.1023/A:1014541222816.

Kohshima S. 1984. A novel cold tolerant insect found in a Himalayan glacier. Nature 310:225-227. doi:10.1038/310225a0.

Kohshima S. 1985. Patagonian glaciers as insect habitats. In: Nokajima C, editor. Glaciological studies in Patagonia Northern Icefield. Kyoto: Data Center for Glacier Research Japanese Society of Snow and Ice. pp. 94-99.

Laybourn-Parry J, Tranter M, Hodson AJ. 2012. The ecology of snow and ice environments. Oxford, UK: Oxford University Press.

Lison L. 1960. Statistique appliquée à la biologie expérimentale. La planification de l'expérience et l'analyse des résultats. Population 3:567-578.

Mihalcea C, Brock BW, Diolaiuti G, D'Agata C, Citterio M, Kirkbride MP, Cutler MEJ, Smiraglia C. 2008. Using 
ASTER satellite and ground-based surface temperature measurements to derive supraglacial debris cover and thickness patterns on Miage Glacier (Mont Blanc Massif, Italy). Cold Regions Science and Technology 52:341-354. doi:10.1016/j. coldregions.2007.03.004.

Nakawo M, Rana B. 1999. Estimate of ablation rate of glacier ice under a supraglacial debris layer. Geografiska Annaler, Series A: Physical Geography 81:695-701. doi:10.1111/geoa.1999.81. issue-4.

Nakawo M, Raymond CF, Fountain A. 2000. Debris-covered glaciers. International Association of Hydrological Sciences, Publication No. 264. Wallingford: IAHS Press.

Nkem JN, Wall DH, Virginia RA, Barrett JE, Broos EJ, Porazinska DL, Adams BJ. 2006. Wind dispersal of soil invertebrates in the McMurdo Dry Valleys, Antarctica. Polar Biology 29:346352. doi:10.1007/s00300-005-0061-x.

Pelfini M, Diolaiuti GA, Leonelli G, Bozzoni M, Bressan N, Brioschi D. 2012. The influence of glacier surface processes on the short-term evolution of supraglacial tree vegetation: The case study of the Miage Glacier, Italian Alps. The Holocene 22:847-856. doi:10.1177/0959683611434222.

Pelfini M, Santilli M, Leonelli G, Bozzoni M. 2007. Investigating surface movements of debris-covered Miage glacier, Western Italian Alps, using dendroglaciological analysis. Journal of Glaciology 53:141-152. doi:10.3189/ 172756507781833839.

Peneva V, Bongers AMT 2013. Nematoda. Fauna Europaea version 2.6.2. Web service. Available: http://www.faunaeur.org. Accessed Aug 20151.

Schütte S, Abdo Z, Foster J, Ravel J, Bunge J, Solheim B, Forney LJ. 2010. Bacterial diversity in a High Arctic glacial foreland. Molecular Ecology 19:54-66. doi:10.1111/j.1365-294X.2009. 04479.x.

Segers H, De Smet WH, Fischer C, Fontaneto D, Michaloudi E, Wallace RL, Jersabek CD. 2012. Towards a list of available names in zoology, partim Phylum Rotifera. Zootaxa 3179:61-68.
Seinhorst JW. 1959. A rapid method for the transfer of nematodes from fixative to anhydrous glycerin. Nematologica 4:67-69. doi:10.1163/187529259X00381.

Shain DH, Mason TA, Farrell AH, Michalewicz LA. 2001. Distribution and behavior of ice worms (Mesenchytraeus solifugus) in south-central Alaska. Canadian Journal of Zoology 79:1813-1821. doi:10.1139/z01-143.

Sieriebriennikov B, Ferris H, De Goede RGM. 2014. NINJA: An automated calculation system for nematode-based biological monitoring. European Journal of Soil Biology 61:90-93. doi:10.1016/j.ejsobi.2014.02.004.

Smiraglia C, Azzoni RS, D'Agata C, Maragno D, Fugazza D, Diolaiuti GA. 2015. The evolution of the Italian glaciers from the previous data base to the New Italian Inventory. Preliminary considerations and results. Geografia Fisica e Dinamica Quaternaria. 38:79-87.

Sohlenius B, Boström S, Hirschfelder A. 1996. Distribution patterns of microfauna (nematodes, rotifers and tardigrades) on nunataks in Dronning Maud Land, East Antarctica. Polar Biology 16:191-200. doi:10.1007/BF02329207.

Stibal M, Tranter M, Benning LG, Rěhák J. 2008. Microbial primary production on an Arctic glacier is insignificant in comparison with allochthonous organic carbon input. Environmental Microbiology 10:2172-2178. doi:10.1111/ j.1462-2920.2008.01620.x.

Takeuchi N, Kohshima S, Seko K. 2001. Structure, formation, and darkening process of albedo-reducing material (cryoconite) on a Himalayan glacier: A granular algal mat growing on the glacier. Arctic, Antarctic, and Alpine Research 33:115-122. doi:10.2307/1552211.

Zawierucha K, Kolicka M, Takeuchi N, Kaczmarek L. 2015. What animals can live in cryoconite holes? A faunal review. Journal of Zoology 295:159-169. doi:10.1111/jzo.2015.295. issue-3.

Zuur AF, Ieno EN, Walker NG, Saveliev AA, Smith GM. 2009. Mixed effects models and extensions in ecology with $\mathrm{R}$. New York: Springer. 